\title{
Regulation of Uterine Spiral Artery Remodeling: a Review
}

\author{
Eugene D. Albrecht ${ }^{1,2}$ (D) Gerald J. Pepe ${ }^{3}$
}

Received: 11 February 2020 / Accepted: 6 May 2020 / Published online: 16 June 2020

(C) The Author(s) 2020

\begin{abstract}
Extravillous trophoblast remodeling of the uterine spiral arteries is essential for promoting blood flow to the placenta and fetal development, but little is known about the regulation of this process. A defect in spiral artery remodeling underpins adverse conditions of human pregnancy, notably early-onset preeclampsia and fetal growth restriction, which result in maternal and fetal morbidity and mortality. Many in vitro studies have been conducted to determine the ability of growth and other factors to stimulate trophoblast cells to migrate across a synthetic membrane. Clinical studies have investigated whether the maternal levels of various factors are altered during abnormal human pregnancy. Animal models have been established to assess the ability of various factors to recapitulate the pathophysiological symptoms of preeclampsia. This review analyzes the results of the in vitro, clinical, and animal studies and describes a nonhuman primate experimental paradigm of defective uterine artery remodeling to study the regulation of vessel remodeling.
\end{abstract}

Keywords Uterine artery remodeling $\cdot$ Preeclampsia $\cdot$ Animal models

\section{Introduction}

During early human pregnancy, extravillous trophoblast (EVT) migrates to, invades, and replaces the vascular smooth muscle cells (VSMC), endothelial cells, and elastic lamina within, thereby remodeling the uterine spiral arteries [1-4]. Consequently, these arteries change from high-resistance/ low-capacity to low-resistance/high-capacity vessels, and thus, uterine artery blood flow increases with advancing gestation to enhance placental perfusion and promote fetal development. Defective uterine artery remodeling (UAR) underpins the etiology of certain pregnancy disorders that comprise the syndrome of placental ischemia $[5,6]$, notably early-onset preeclampsia, defined as premature delivery prior to week 34

Eugene D. Albrecht

ealbrecht@som.umaryland.edu

1 Bressler Research Laboratories, Department of Obstetrics, Gynecology and Reproductive Sciences, University of Maryland School of Medicine, 655 West Baltimore St., Baltimore, MD, USA

2 Department of Physiology, University of Maryland School of Medicine, Baltimore, MD, USA

3 Department of Physiological Sciences, Eastern Virginia Medical School, Norfolk, VA, USA of gestation and associated with a high rate of fetal growth restriction [7-13]. The term preeclampsia is used throughout this review to refer to early onset since in contrast to late-onset preeclampsia, i.e., delivery after 34 weeks, it is underpinned by defective UAR. Preeclampsia is associated with maternal systemic vascular endothelial inflammation-activation-dysfunction, hypertension, renal glomerular endotheliosis, and proteinuria, as well as maternal and neonatal morbidity/ mortality [14-20]. It has been proposed that as a consequence of impaired UAR and placental perfusion, the placenta exhibits oxidative stress and the release of anti-angiogenic factors, cytokines, and/or syncytial extracellular vesicles which, along with predisposing maternal factors such as obesity and hypertension, elicit the pathophysiological manifestations of preeclampsia (reviewed in $[16,20]$ ). Excessive trophoblast invasion and UAR are also deleterious because they result in impaired uterine artery vasomotor tone and hemorrhaging after delivery, a pregnancy complication known as placenta accreta $[21,22]$. Despite the fundamental importance of UAR to successful pregnancy and fetal development, relatively little is known about the regulation of this process primarily because the majority of studies have focused on the pathophysiological consequences of adverse conditions of pregnancy and not on UAR. The present review describes the results of the in vitro and in vivo studies and a nonhuman primate model to study the regulation of UAR. 


\section{In Vitro Studies}

Numerous in vitro studies have been conducted to investigate the ability of primary or immortalized trophoblasts cultured in two or three dimensions to pass across a synthetic permeable membrane coated with matrigel or decellularized extracellular matrix or to form endothelial-like tubes as indices of cell migration and invasion. Collectively, these studies have shown that several factors known to be produced by the placenta and/ or decidua, including vascular endothelial growth factor-A (VEGF), placental growth factor (PIGF), insulin-like growth factor (IGF), epidermal growth factor (EGF), heparin-binding EGF (HB-EGF), activin, and human chorionic gonadotrophin (hCG), stimulated HTR-8/SV neo, trophoblast, or choriocarcinoma JEG-3 cell migration or endothelial-like tube formation [23-33]. Moreover, transcription and cell signaling molecules, including the Rac1 member of the Rho family of GTPases, the elastin-derived matrikine VGVAPG, the ephrin-B2 ligand of the Eph receptor, and Notch-2, also increased trophoblast migratory capacity in vitro [34-38]. However, in other in vitro studies, several of these factors did not alter EVT migration [39-41]. In contrast, transforming growth factor (TGF $\beta$ )-1, TGF $\beta-2$, and TGF $\beta-3$ and endocrine gland VEGF (EG-VEGF), as well as microRNA-93 and microRNA-135 which decrease CXCL12 gene expression, inhibited migration/invasive capacity of trophoblasts [42-47], while inhibition of TGF $\beta 3$ restored invasive capacity of trophoblasts obtained in late gestation from placentas of women with preeclampsia [48]. Additional in vitro studies using placental explants showed that elastin-derived peptides increased and endothelin-1 decreased trophoblast overgrowth $[35,49]$. The underlying causes of the divergent effects of these factors on trophoblast migration are unclear, although use of different culture conditions, including oxygen and hypoxia-inducible factor levels and transformed versus primary trophoblasts, may be involved.

The presence of uterine natural killer (uNK) cells and macrophages, which are sources of VEGF-A and VEGF-C, angiopoietins, interleukins, and matrix metalloproteinases (MMPs) [50], was associated with VSMC and endothelial cell disruption in decidual tissue obtained in early human pregnancy [51], while the addition of UNK cell-conditioned medium to cultures of human term chorionic plate arteries caused VSMC and extracellular matrix breakdown [52]. The addition of EVT-conditioned medium to cultures of vascular endothelial cells increased expression of the chemokines CCL14 and CXCL6, which induced chemotaxis of decidual NK cells and macrophages, and the authors proposed that there was crosstalk between EVT, endothelial cells, and decidual immune cells in spiral artery remodeling [53]. NK cells also enhanced migration of and tube formation by primary trophoblast cells from placental villous tips, an effect that was prevented in cultures containing NK cells pretreated with sphingosine FTY720 to suppress NK cell function and VEGF production [54]. Moreover, recent studies suggest that additional processes, including invasion of uterine veins and lymph vessels by endo-venous and endo-lymphatic trophoblast cells, respectively, may also be involved in uterine artery remodeling [55, 56]. Based on these studies, it has been proposed that the immune system plays a role in uterine vessel transformation, although it has been suggested that the role of the immune system is more established in mouse than in human pregnancy (reviewed in [57-59]).

Clearly, the in vitro studies are significant in showing that a multitude of factors have the capacity to alter migratory and invasive capacity of trophoblast cells. However, considering the highly complex interplay of different cell types, molecular events, and spatio-temporal cell interactions that occur in vivo during spiral artery transformation, it is unclear whether trophoblast migration and endothelial tube formation as assessed in vitro validly mirror the process of UAR as it occurs in vivo. Thus, in vivo animal studies are needed to ascertain the applicability and physiological role of the candidate factors shown in vitro either operating alone or in conjunction with each other in regulating UAR.

\section{Clinical Studies}

Human clinical studies have shown that placental expression and/or maternal serum levels of many growth factors, including VEGF, IGF-I, EGF, HB-EGF, TGF $\beta$, soluble endoglin, and other peptides, as well as Notch-2, endothelial colonyforming cells, tyrosine kinase-like orphan receptor, and microRNA-93, are either elevated, decreased, or unaltered in mid to late gestation in women who develop preeclampsia [23, 26, 60-70]. Additional studies have shown that maternal serum levels of PlGF are decreased, and the levels of the sFlt-1 soluble truncated VEGF receptor that binds to and suppresses VEGF bioavailability and endoglin were increased, preceding or coinciding with onset of the complications, e.g., maternal vascular dysfunction, of preeclampsia [71-78]. Consequently, it has been suggested that an imbalance in the levels of antiangiogenic and angiogenic proteins and other factors may serve as biomarkers that are predictive for early detection of preeclampsia (reviewed in $[19,79,80]$ ).

Studies have also shown either an increase, no change, or a decrease in maternal serum estradiol levels at mid to late gestation in women exhibiting preeclampsia [81-87]. However, the role of estradiol in early human pregnancy with respect to UAR and onset of the pathophysiological conditions associated with preeclampsia has not been investigated.

Clinical studies have also shown that the number of immune cells, notably uNK cells, macrophages, and dendritic cells is either increased [88-94], decreased [95-97], or not altered [98-100] in decidua/placental bed obtained in late 
gestation before (e.g., biopsies) or after parturition in patients with preeclampsia. Studies also indicate that women with preeclampsia primarily express the inhibitory and not the stimulatory KIR receptors for uNK cells and that women with a KIR AA genotype, i.e., predictive of expression of the inhibitory KIRs KIR2DL-1, KIR2DL-2, KIR2DL-3, and KIR2DL5 , are at increased risk for developing preeclampsia [101]. Macrophages are also differently activated in preeclampsia [102-106], which may reflect a decrease in M2 macrophages and a concomitant increase in M1 macrophages [92] in the placental bed of preeclamptic women. Such a change would be consistent with increased placental production of proinflammatory cytokines [107] and decreased formation of anti-inflammatory cytokines $[108,109]$ that occur in preeclampsia. Interestingly the levels of mRNAs for immuneassociated genes, notably IL-6 and macrophages, as well as markers for expression of M2 macrophages [110] are greater in biopsies of decidua from women in early gestation who subsequently developed pregnancy-induced hypertension compared with those who remained normotensive.

The human studies have been important in correlating the levels of the various factors with the pathophysiological features of preeclampsia. However, it is difficult to test cause and effect and the alterations in the various factors at mid-late gestation in preeclampsia patients may result from and not underpin the pathophysiological conditions elicited by preeclampsia. Importantly, since UAR was not simultaneously examined in these clinical studies, the regulatory role of these factors on UAR has not been established in normal or adverse human pregnancy.

\section{Animal Studies}

As presented in recent reviews [16, 19, 20, 111], early-onset preeclampsia is considered a two-stage disorder, stage 1 reflecting reduced placental perfusion and dysfunction due to impaired UAR and stage 2 the maternal syndrome induced by inadequate placental perfusion and deportation into the maternal blood of placental factors and syncytial particles produced in response to placental hypoxia and oxidative stress (Fig. 1). Although the maternal disorder including organ system involvement can vary greatly in complexity and severity $[16,111]$, maternal systemic vascular dysfunction and hypertension are hallmark features of preeclampsia. These manifestations appear to result from vascular endothelial inflammation, oxidative stress and dysfunction, notably impaired ability to produce the vasodilators nitric oxide $(\mathrm{NO})$ and prostacyclin $\mathrm{I}_{2}$, increased production of vasoconstrictors such as endothelin, and hyper-sensitivity of VSMC to vasoconstrictors within the vascular bed (Fig. 2) $[12,14,16-18,20$, 112-121].
It is well established that VEGF plays a pivotal role in promoting vascular endothelial cell integrity, stability, and function, including NO production [122-124]. Therefore, it has been hypothesized $[19,75,117]$ that in preeclampsia the placental ischemia induced by defective UAR causes an increase in placental expression and maternal serum levels of sFlt-1, which decreases VEGF bioavailability and elicits maternal vascular dysfunction (Fig. 2). Accordingly, animal models have been developed to examine this hypothesis and ascertain the possibility of achieving a therapeutic approach to overcome or prevent the vascular dysfunction elicited by decreased bioavailability of VEGF. Thus, key manifestations of preeclampsia, i.e., maternal hypertension, fetal growth restriction, and/or maternal vascular endothelial dysfunction, were induced in mice or rats in which levels of sFlt1 and/or endoglin were elevated by systemic adenoviral delivery of these proteins [74, 125-131]. Systemic administration to mice of an antibody which neutralized both Flt- 1 and sFlt- 1 decreased uterine artery length as an index of arterial transformation in this species [132]. The clinical manifestations of preeclampsia elicited in several of these animal models were prevented by adenoviral delivery of $\mathrm{VEGF}_{121}$ [133-138]. Symptoms of preeclampsia were also overcome in lentiviral sFlt1-treated mice by concomitant administration of the drug pravastatin [139] and in BPH/5 mice by injection of the drug celecoxib at the time of embryo implantation, which apparently acted by restoring the levels of Cox 2, VEGF, and related angiogenic factors [140]. Mice defective for PIGF, a member of the VEGF family, also exhibit preeclampsia-like symptoms, notably maternal endothelial dysfunction, as well as cognitive function of the offspring [141, 142]. Moreover, an experimental increase in sFlt-1 levels or decrease in VEGF and PIGF levels induced in rats and sheep by aortic or uterine artery ligation to elicit placental ischemia caused maternal hypertension, proteinurea, and vascular dysfunction, effects reversed by VEGF or PIGF administration [135, 138, 143-145]. Uterine spiral arteriole remodeling and MMP-2 and MMP-9 were decreased in the rat reduced uterine perfusion pressure model [146].

Inhibition of NO synthase [147], as well as administration of tumor necrosis factor- $\alpha$ [143] or interleukin [148], also induced preeclampsia-like symptoms in mice and rats. Interestingly, uterine artery diameter and length were reduced in endothelial NO synthase-null mice [149], whereas nanoparticle-mediated delivery of the NO donor SE175 to mice at mid-late gestation increased spiral artery diameter [150]. Roles for the Notch signaling pathway and the storkhead box 1 (STOX 1) transcription factor have also been suggested since Notch 2-null mice exhibited a decrease in spiral artery diameter and placental perfusion [151], while overexpression of STOX 1 in mice led to a preeclampsia phenotype of hypertension [152]. 
Fig. 1 The two-stage placental model of preeclampsia in which it has been proposed [111] that impaired remodeling of uterine spiral arteries ("poor

placentation") is the pathway to stage 1 preeclampsia (placental dysfunction) and the preclinical stage before development of the maternal clinical syndrome (stage 2). Reprinted from Staff [20]
1991: Preeclampsia: a two stage placental disorder

How poor placentation leads to maternal endothelial dysfunction

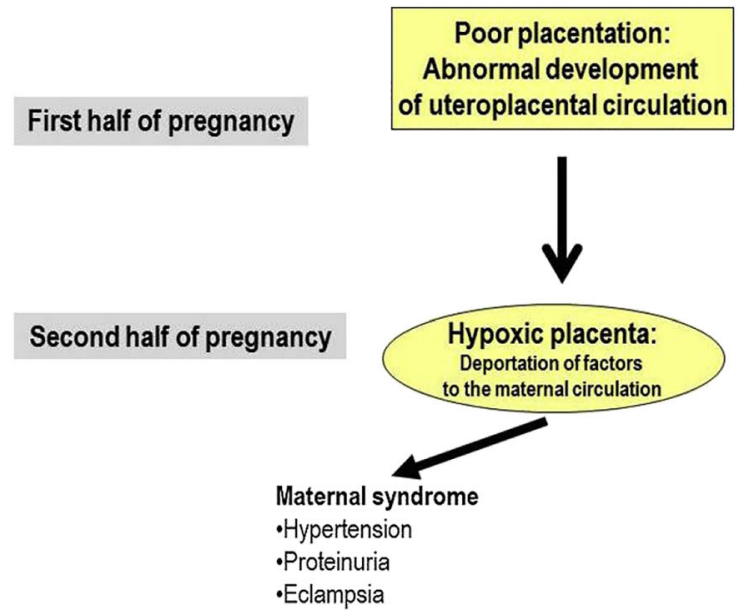

Stage 1: Pre-clinical

Stage 2: Clinical
The role of immune cells in the process of vessel transformation has been proposed. Thus, studies in uNK cellimmunodeficient mice indicate that uNK cells, via the formation of interferon gamma, promote modification (i.e., luminal area) of spiral arteries [153-156]. Moreover, T lymphocyte regulatory cell (Tregs)-deficient mice show impaired uterine artery remodeling and flow $[157,158]$, suggesting that Tregs impair inflammatory responses that cause a defect in uterine vessel transformation [159].

Evidence for involvement of the renin-angiotensin (AT)aldosterone system in preeclampsia has also emerged from rodent models. Thus, administration of antibodies to $\mathrm{AT}_{1}$ beginning at midgestation to mice or rats elicited hypertension, proteinuria, glomerular endotheliosis, and placental abnormalities [160, 161]. Moreover, $\mathrm{AT}_{1}$-deficient mice exhibited impaired placentation [162], and angiotensinogen transgenic mice exhibited deeper endovascular trophoblast invasion and spiral artery remodeling [163]. Upregulation of VSMC $\mathrm{AT}_{1}$ expression elicited hypertension, proteinuria, increased sFlt-1 expression, and decreased placental labyrinth growth in mice, effects prevented by administration of $\beta$-arrestin, a $\mathrm{G}$ protein that causes $\mathrm{AT}_{1}$ receptor desensitization [164].

The rodent models have been valuable in recapitulating the clinical symptoms of pregnancy disorders such as preeclampsia. However, in most instances, UAR was not examined, experimental interventions used to induce preeclampsia-like
Fig. 2 Hypothetical scheme depicting how abnormal trophoblast invasion and spiral artery remodeling result in placental ischemia, endothelial dysfunction, and hypertension in preeclampsia. Reprinted from Palei et al. [17]

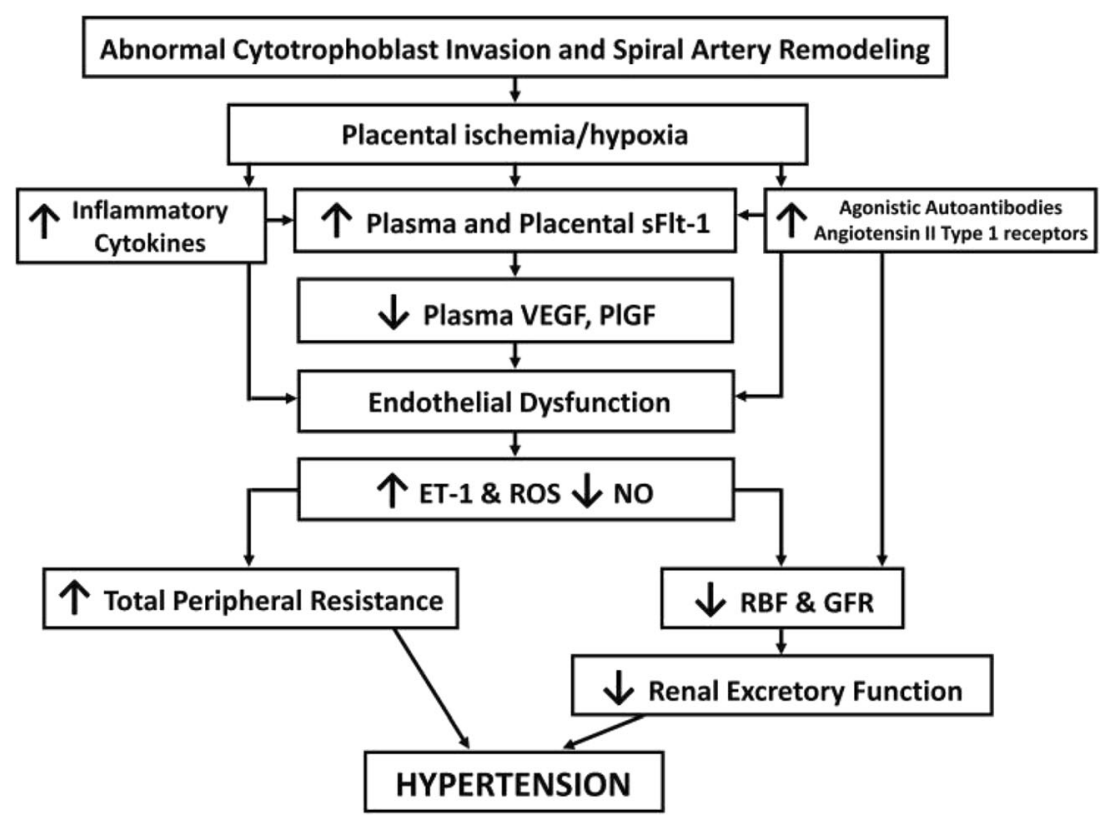


Fig. 3 (a) sFlt-1 levels in uterine vein and (b) VEGF protein quantified by proximity ligation assay (signals/nuclear area $\times 10^{4}$ ) in the anchoring villi on day 60 in untreated and estradiol $\left(\mathrm{E}_{2}\right)$ treated baboons. $* P<0.05$

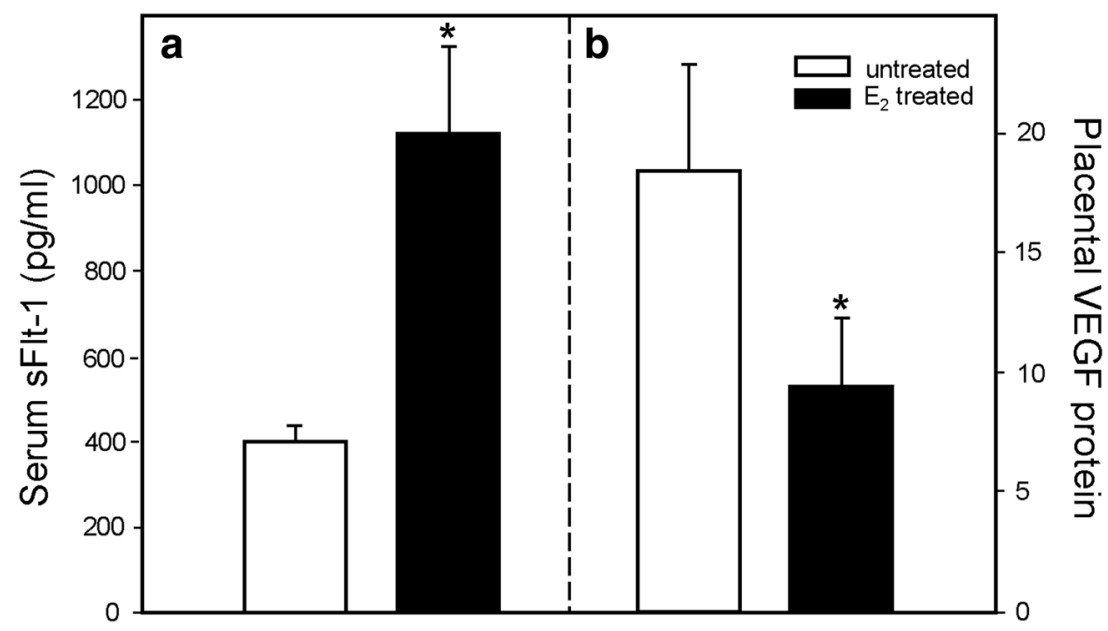

symptoms were often applied after the time of placentation, and many of the clinical features of preeclampsia were also induced in nonpregnant rodents, and thus, these models were not specific for pregnancy. Moreover, there are significant differences in placental morphology and development, the process and impact of spiral artery remodeling, uterine and placental vascular anatomy, and the maternal-placenta-fetal endocrine inter-relationships between rodents and humans [58, 59, 165-171]. For example, in the mouse and rat, trophoblast invasion is temporally restricted to late gestation [58, 172] and the role of UAR on maternal vascular function may be equivocal. Thus, although NK-defective mice exhibit impaired UAR, maternal resting blood pressure remains normal throughout gestation and maternal proteinuria does not develop [155], while trophoblast arterial invasion is more extensive and uterine artery resistance lower in the rat $\mathrm{BHP} / 5$ model of preeclampsia [163]. Collectively, these differences

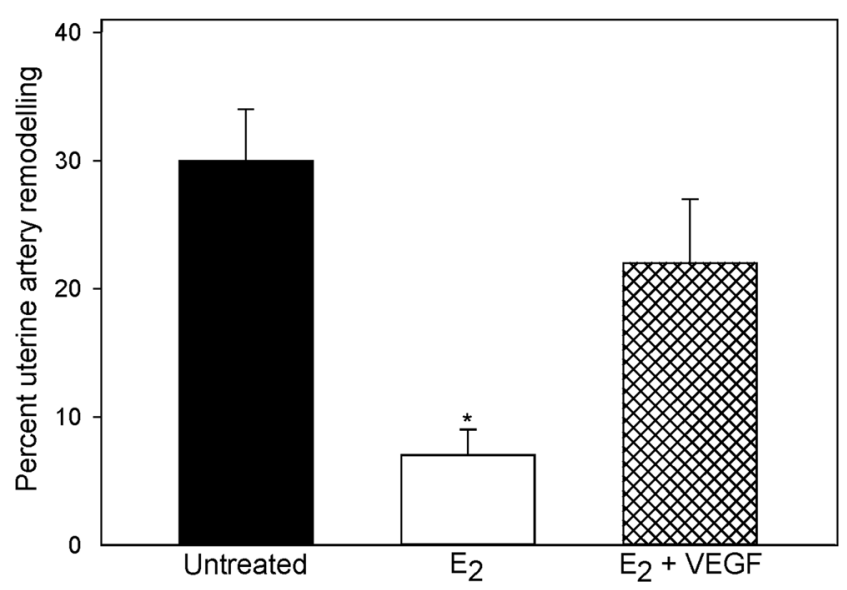

Fig. 4 Percent remodeling of uterine spiral arteries (i.e., number of vessels exhibiting trophoblast invasion divided by total number of vessels counted) on day 60 of gestation in baboons untreated, treated with estradiol $\left(\mathrm{E}_{2}\right)$, or treated with $\mathrm{E}_{2}$ plus VEGF DNA. *Different $(P<0.01)$ from values in other two groups between rodents and humans make translation of findings on UAR in the rodent to the human uncertain.

Although rodents have been extensively used to recapitulate the pathophysiological features of preeclampsia, relatively few studies have employed nonhuman primates in this area of perinatal biology. Placental morphology, the process of uterine spiral artery transformation, uterine and placental vascular anatomy, and maternal-placental-fetal endocrine interrelationships are similar in human and baboon pregnancy $[58,165,173]$. Although remodeling of the spiral arteries in the baboon does not extend into the inner myometrium, as in human pregnancy, the qualitative nature of placentation and UAR are alike [58, 174]. In addition to these important considerations, humans and baboons exhibit similar anatomy, physiology, and ontogeny of the fetal-placental unit [165] and share $>96 \%$ DNA/genetic homology $[175,176]$, and thus, the baboon provides an excellent nonhuman primate model for the study of human placental and fetal development.

As in the rodent studies, uterine artery ligation has been employed as an experimental paradigm in pregnant baboons. Uteroplacental ischemia elicited by uterine artery ligation in the second half of baboon pregnancy resulted in hypertension, proteinuria, and renal endotheliosis, effects reversed by administration of sFlt-1 siRNA or PlGF [177-180]. Thus, the latter primate studies focused on recapitulating the symptoms of adverse human pregnancy but not on UAR.

In contrast to the latter approach, the authors have published a series of studies in which they have established an experimental paradigm of prematurely elevating estradiol levels in the first trimester of baboon pregnancy to study the regulation of UAR [181-183]. Slightly elevating maternal estradiol levels resulted in a 3 -fold increase in placental expression and maternal serum levels of sFlt-1 and decrease in extravillous trophoblast expression of VEGF in early pregnancy (Fig. 3). The increase in sFlt-1/decrease in VEGF was associated with a $75 \%$ reduction in the level of UAR, quantified as the percent of uterine spiral arteries invaded and 
remodeled by extravillous trophoblasts, at the end of the first trimester (Fig. 4). Concomitant administration of estradiol and delivery of the VEGF gene selectively to the maternal aspect of the placenta, but not the fetus, by contrast-enhanced ultrasonography/microbubble technology restored VEGF protein levels and prevented the decrease in UAR (Fig. 4, [184]).

The decline in extravillous trophoblast VEGF expression in estradiol-treated baboons was associated with a decrease in expression of the $\alpha_{1} \beta_{1}$ and $\alpha_{5} \beta_{1}$ integrins [182] that promote trophoblast migration and remodeling and are increased by VEGF in vitro [185-187]. This suggests that these integrins may mediate the stimulatory effect of VEGF on UAR during early baboon pregnancy. Coinciding with the decrease in UAR, uterine artery blood flow was reduced by $30 \%$ and maternal blood pressure increased by $25 \%$ near term, suggesting an impairment of maternal systemic vascular function [183]. Although it has been suggested that the alteration in expression of pro- and anti-angiogenic growth factors is simply the result and not the cause of placental dysfunction in preeclampsia [20], the prevention of the decrease in UAR by VEGF delivery in early baboon pregnancy is consistent with VEGF having a pivotal role in promoting UAR.

\section{Summary}

UAR is vital to successful pregnancy; however, the regulation of this fundamentally important process has not been established. The in vitro studies are important in having identified a multitude of factors that have the ability to alter migratory and invasive capacity of trophoblast cells. However, it is unclear whether trophoblast migration and endothelial tube formation as assessed in vitro validly mirror the process of UAR as it occurs in vivo. The clinical studies have been significant in showing that maternal serum levels of certain factors are altered, particularly sFlt-1 which is increased and PlGF which is decreased, preceding or coinciding with onset of the complications, e.g., maternal vascular dysfunction, emanating from preeclampsia. However, it is difficult to test cause and effect in human pregnancy studies, and thus, the alteration in circulating levels of the various factors may be a consequence of and not underpin the pathophysiological conditions elicited by adverse pregnancy. The rodent and a few primate studies have been valuable in recapitulating, and showing the ability of certain growth factors to mitigate, the clinical manifestations of pregnancy disorders such as preeclampsia, but have not focused on UAR. This review has described the results of in vitro, clinical, and rodent studies and also a novel experimental model of defective UAR in a nonhuman primate that allows study of the regulation of spiral artery transformation and the potential to develop therapeutic modalities to manage or prevent the maternal pathophysiological consequences of adverse pregnancy arising from defective UAR.
Acknowledgments The authors thank Irene Baranyk, B.A., and Sandra Huband for the computer-assisted preparation of this manuscript.

Funding Information This work was supported by National Institutes of Health R01 HD 93070 and R01 HD 93946.

\section{Compliance with Ethical Standards}

Conflict of Interest The authors declare that they have no conflicts of interest.

Open Access This article is licensed under a Creative Commons Attribution 4.0 International License, which permits use, sharing, adaptation, distribution and reproduction in any medium or format, as long as you give appropriate credit to the original author(s) and the source, provide a link to the Creative Commons licence, and indicate if changes were made. The images or other third party material in this article are included in the article's Creative Commons licence, unless indicated otherwise in a credit line to the material. If material is not included in the article's Creative Commons licence and your intended use is not permitted by statutory regulation or exceeds the permitted use, you will need to obtain permission directly from the copyright holder. To view a copy of this licence, visit http://creativecommons.org/licenses/by/4.0/.

\section{References}

1. Hamilton WJ, Boyd JD. Development of the human placenta in the first three months of gestation. J Anat. 1960;94:297-328.

2. Ramsey EM, Houston ML, Harris JW. Interactions of the trophoblast and maternal tissues in three closely related primate species. Am J Obstet Gynecol. 1976;124:647-52.

3. Pijnenborg R, Dixon G, Robertson WB, Brosens I. Trophoblastic invasion of human decidua from 8 to 18 weeks of pregnancy. Placenta. 1980;1:3-19.

4. Enders AC, King BF. Early stages of trophoblastic invasion of the maternal vascular system during implantation in the macaque and baboon. Am J Anat. 1991;192:329-46.

5. Ananth CV. Ischemic placental disease: a unifying concept for preeclampsia, intrauterine growth restriction, and placental abruption. Semin Perinatol. 2014;38:131-2.

6. Heazell AE, Worton SA, Higgins LE, Ingram E, Johnstone ED, Jones RL, et al. IFPA Gábor Than Award Lecture: recognition of placental failure is key to saving babies' lives. Placenta. 2015;36: S20-8.

7. Brosens I. A study of the spiral arteries of the decidua basalis in normotensive and hypertensive pregnancies. J Obstet Gynaecol Br Commonw. 1964;71:222-30.

8. Khong TY, De Wolf F, Robertson WB, Brosens I. Inadequate maternal vascular response to placentation in pregnancies complicated by pre-eclampsia and by small-for-gestational age infants. Br J Obstet Gynaecol. 1986;93:1049-59.

9. Pijnenborg R, Vercruysse L, Hanssens M. The uterine spiral arteries in human pregnancy: facts and controversies. Placenta. 2006;27:939-58.

10. Lyall F, Robson SC, Bulmer JN. Spiral artery remodeling and trophoblast invasion in preeclampsia and fetal growth restriction: relationship to clinical outcome. Hypertension. 2013;62:1046-54.

11. Brosens I, Puttemans P, Benagiano G. Placental bed research: I. The placental bed: from spiral arteries remodeling to the great obstetrical syndromes. Am J Obstet Gynecol. 2019;221(5):43756. 
12. Myatt L, Roberts JM. Preeclampsia: syndrome or disease? Curr Hypertens Rep. 2015;17(11):83.

13. Burton GJ, Jauniaux E. Pathophysiology of placental-derived fetal growth restriction. Am J Obstet Gynecol. 2018;218:S745-61.

14. Roberts JM, Taylor RN, Goldfien A. Clinical and biochemical evidence of endothelial cell dysfunction in the pregnancy syndrome preeclampsia. Am J Hypertens. 1991;4:700-8.

15. Gilbert JS, Ryan MJ, LaMarca BB, Sedeek M, Murphy SR, Granger JP. Pathophysiology of hypertension during preeclampsia: linking placental ischemia with endothelial dysfunction. Am J Physiol Heart Circ Physiol. 2008;294:H541-50.

16. Roberts JM, Bell MJ. If we know so much about preeclampsia, why haven't we cured the disease? J Reprod Immunol. 2013;99: $1-9$

17. Palei AC, Spradley FT, Warrington JP, George EM, Granger JP. Pathophysiology of hypertension in pre-eclampsia: a lesson in integrative physiology. Acta Physiol. 2013;208:224-33.

18. Granger JP, Spradley FT, Bakrania BA. The endothelin system: a critical player in the pathophysiology of preeclampsia. Curr Hypertens Rep. 2018;20:32.

19. Rana S, Lemoine E, Granger J, Karumanchi SA. Preeclapmsia. Circ Res. 2019;124:1094-112.

20. Staff AC. The two-stage placental model of preeclampsia: an update. J Reprod Immunol. 2019;134-135:1-10.

21. Tantbirojn P, Crum CP, Parast MM. Pathophysiology of placenta creta: the role of decidua and extravillous trophoblast. Placenta. 2008;29:639-45.

22. Hannon T, Innes BA, Lash GE, Bulmer JN, Robson SC. Effects of local decidua on trophoblast invasion and spiral artery remodeling in focal placenta creta - an immunohistochemical study. Placenta. 2012;33:998-1004

23. Zhou Y, McMaster M, Woo K, Janatpour M, Perry J, Karpanen T, et al. Vascular endothelial growth factor ligands and receptors that regulate human cytotrophoblast survival are dysregulated in severe preeclampsia and hemolysis, elevated liver enzymes, and low platelets syndrome. Am J Pathol. 2002;160:1405-23.

24. Lala PK, Chakraborty C. Factors regulating trophoblast migration and invasiveness: possible derangements contributing to preecclampsia and fetal injury. Placenta. 2003;24:575-87.

25. Anteby EY, Greenfield C, Natanson-Yaron S, Goldman-Wohl D, Hamani Y, Khudyak V, et al. Vascular endothelial growth factor, epidermal growth factor and fibroblast growth factor-4 and -10 stimulate trophoblast plasminogen activator system and metalloproteinase-9. Mol Hum Reprod. 2004;10:229-35.

26. Leach RE, Kilburn B, Wang J, Liu Z, Romero R, Armant DR. Heparin-binding EGF-like growth factor regulates human extravillous cytotrophoblast development during conversion to the invasive phenotype. Dev Biol. 2004;266:223-37.

27. Lyall F. Priming and remodelling of human placental bed spiral arteries during pregnancy - a review. Placenta. 2005;26:S31-6.

28. Rao CV, Lei ZM. The past, present and future of nongonadal LH/ hCG actions in reproductive biology and medicine. Mol Cell Endocrinol. 2007;269:2-8.

29. Harris LK. Review: Trophoblast-vascular cell interactions in early pregnancy: how to remodel a vessel. Placenta. 2010;31:S93-8.

30. Knöfler M, Pollheimer J. IFPA Award in Placentology lecture: molecular regulation of human trophoblast invasion. Placenta. 2012;33:S55-62.

31. Lala N, Girish GV, Cloutier-Bosworth A, Lala PK. Mechanisms in decorin regulation of vascular endothelial growth factorinduced human trophoblast migration and acquisition of endothelial phenotype. Biol Reprod. 2012;87(59):1-14.

32. Li Y, Zhu H, Klausen C, Peng B, Leung PC. Vascular endothelial growth factor-A (VEGF-A) mediates activin A-induced human trophoblast endothelial-like tube formation. Endocrinology. 2015;156:4257-68
33. Evans J, Salamonsen LA, Menkhorst E, Dimitradis E. Dynamic changes in hyperglycosylated human chorionic gonadotrophin throughout the first trimester of pregnancy and its role in early placentation. Hum Reprod. 2015;30:1029-38.

34. Luo Q, Liu X, Zheng Y, Zhao Y, Zhu J, Zou L. Ephrin-B2 mediates trophoblast-dependent maternal spiral artery remodeling in first trimester. Placenta. 2015;36:567-74.

35. Deforges M, Harris LK, Alpin JD. Elastin-derived peptides stimulate trophoblast migration and invasion: a positive feedback loop to enhance spiral artery remodelling. Mol Hum Reprod. 2015;21: 95-104.

36. Fan $\mathrm{M}, \mathrm{Xu} \mathrm{Y}$, Hong $\mathrm{F}$, Gao X, Xin $\mathrm{G}$, Hong H, et al. Rac1/ $\beta$ catenin signalling pathway contributes to trophoblast cell invasion by targeting snail and MMP9. Cell Physiol Biochem. 2016;38: 1319-32.

37. Zhao WX, Zhuang X, Huang TT, Feng R, Lin JH. Effects of Notch 2 and Notch 3 on cell proliferation and apoptosis of trophoblast cell lines. Int J Med Sci. 2015;12:867-74.

38. McNally R, Alqudah A, Obradovic D, McClements L. Elucidating the pathogenesis of pre-eclampsia using in vitro models of spiral uterine artery remodelling. Curr Hypertens Rep. 2017;19:93.

39. Athanassiades A, Hamilton GS, Lala PK. Vascular endothelial growth factor stimulates proliferation but not migration or invasiveness in human extravillous trophoblast. Biol Reprod. 1998;59: 643-54.

40. Fitzpatrick TE, Lash GE, Yanaihara A, Charnock-Jones DS, Macdonald-Goodfellow SK, Graham CH. Inhibition of breast carcinoma and trophoblast cell invasiveness by vascular endothelial growth factor. Exp Cell Res. 2003;283:247-55.

41. Dubinsky V, Poehlmann TG, Suman P, Gentile T, Markert UR, Gutierrez G. Role of regulatory and angiogenic cytokines in invasion of trophoblastic cells. Am J Reprod Immunol. 2010;63:1939.

42. Forbes K, Westwood M. Maternal growth factor regulation of human placental development and fetal growth. J Endocrinol. 2010;207:1-16.

43. Jones RL, Findlay JK, Farnworth PG, Robertson DM, Wallace E, Salamonsen LA. Activin A and inhibin A differentially regulate human uterine matrix metalloptoteinases: potential interactions during decidualization and trophoblast invasion. Endocrinology. 2006; 147:724-32.

44. Hu XQ, Zhang L. MicroRNAs in uteroplacental vascular dysfunction. Cells. 2019;8(11):1344.

45. Hoffman P, Saoudi Y, Benharouga M, Graham CH, Schaal JP, Mazouni C, et al. Role of EG-VEGF in human placentation: physiological and pathological implications. J Cell Mol Med. 2009;13: 2224-35.

46. Tamaru S, Mizuno Y, Tochigi H, Kajihara T, Okazaki Y, Okagaki $\mathrm{R}$, et al. MicroRNA-135b suppresses extravillous trophoblastderived HTR-7/SVneo cell invasion by directly down regulating CXCL12 under low oxygen conditions. Biochem Biophys Res Commun. 2015;461:421-6.

47. Pan Q, Niu HY, Cheng LF, Li XQ, Zhang QG, Ning Y. Invasion of trophoblast cell lines is inhibited by miR-93 via MMP-2. Placenta. 2017;53:48-53.

48. Caniggia I, Grisaru-Gravnosky S, Kuliszewsky M, Post M, Lye SJ. Inhibition of TFG-beta 3 restores the invasive capability of extravillous trophoblasts in preeclamptic pregnancies. J Clin Invest. 1999;103:1641-50.

49. Majali-Martinez A, Velicky P, Pollheimer J, Knöfler M, Yung HW, Burton GJ, et al. Endothelin-1 down-regulates matrix metalloproteinase 14 and 15 expression in human first trimester trophoblasts via endothelin receptor type B. Hum Reprod. 2017;32:4654. 
50. Lash GE, Pitman H, Morgan HL, Innes BA, Agwu CN, Bulmer JN. Decidual macrophages: key regulators of vascular remodeling in human pregnancy. J Leukoc Biol. 2016;100:315-25.

51. Smith SD, Dunk CE, Aplin JD, Harris LK, Jones RL. Evidence for immune cell involvement in decidual spiral arteriole remodeling in early human pregnancy. Am J Pathol. 2009;174:1959-71.

52. Robson A, Harris LK, Innes BA, Lash GE, Aljunaidy MM, Aplin $\mathrm{JD}$, et al. Uterine natural killer cells initiate spiral artery remodeling in human pregnancy. FASEB J. 2012;26:4876-85.

53. Choudhury RH, Dunk CE, Lye SJ, Aplin JD, Harris LK, Jones RL. Extravillous trophoblast and endothelial cell crosstalk mediates leukocyte infiltration to the early remodeling decidual spiral arteriole wall. J Immunol. 2017;198(10):4115-28.

54. Zhang J, Dunk CE, Lye SJ. Sphingosine signalling regulates decidual NK cell angiogenic phenotype and trophoblast migration. Hum Reprod. 2013;28:3026-37.

55. Pollheimer J, Vondra S, Baltayeva J, Beristain AG, Knöfler M. Regulation of placental extravillous trophoblasts by the maternal uterine environment. Front Immunol. 2018;9:1-18.

56. Moser G, Windsperger K, Pollheimer J, de Sousa Lopes SC, Huppertz B. Human trophoblast invasion: new and unexpected routes and functions. Histochem Cell Biol. 2018;150:361-70.

57. Harris LK, Benagiano M, D’Elios MM, Brosens I, Benagiano G. Placental bed research: 2. Functional immunological investigations of the placental bed. Am J Obstet Gynecol. 2019;221(5): 457-69.

58. Carter AM. Animal models of human placentation - a review. Placenta. 2007;28(Suppl A):S41-7.

59. Moffet A, Loke C. Immunology of placentation in eutherian mammals. Nat Rev Immunol. 2006;6:584-94.

60. Baker PN, Krasnow J, Roberts JM, Yeo KT. Elevated serum levels of vascular endothelial growth factor in patients with preeclampsia. Obstet Gynecol. 1995;86:815-21.

61. Cooper JC, Sharkey AM, Charnock-Jones DS, Palmer CR, Smith SK. VEGF mRNA levels in placentae from pregnancies complicated by pre-eclampsia. Br J Obstet Gynaecol. 1996;103:1191-6.

62. Sharkey AM, Cooper JC, Balmforth JR, McLaren J, Clark DE, Charnock-Jones DS, et al. Maternal plasma levels of vascular endothelial growth factor in normotensive pregnancies and in pregnancies complicated by pre-eclampsia. Eur J Clin Investig. 1996;26:1182-5.

63. Lyall F, Greer IA, Boswell F, Fleming R. Suppression of serum vascular endothelial growth factor immunoreactivity in normal pregnancy and in pre-eclampsia. Br J Obstet Gynaecol. 1997; 104:223-8.

64. Chung JY, Song Y, Wang Y, Magness RR, Zheng J. Differential expression of vascular endothelial growth factor (VEGF), endocrine gland derived-VEGF, and VEGF receptors in human placentas from normal and preeclamptic pregnancies. J Clin Endocrinol Metab. 2004;89:2484-90.

65. Hamilton GS, Lysiak JJ, Han VK, Lala PK. Autocrine-paracrine regulation of human trophoblast invasiveness by insulin-like growth factor (IGF)-II and IGF-binding protein (IGFBP)-1. Exp Cell Res. 1998;244:147-56.

66. Armant DR, Fritz R, Kilburn BA, Kim YM, Nien JK, Maihle NJ, et al. Reduced expression of the epidermal growth factor signaling system in preeclampsia. Placenta. 2015;6:270-8.

67. Fragkiadaki P, Soulitzis N, Sifakis S, Koutroulakis D, Gourvas V, Vrachnis N, et al. Downregulation of notch signaling pathway in late preterm and term placentas from pregnancies complicated by preeclampsia. PLoS One. 2015;10:e0126163.

68. Muñoz-Hernandez R, Miranda ML, Stiefel P, Lin RZ, PraenaFernández JM, Dominguez-Simeon MJ, et al. Decreased level of cord blood circulating endothelial colony-forming cells in preeclampsia. Hypertension. 2014;64:165-71.
69. Travaglino A, Raffone A, Saccone G, Migliorini S, Maruotti GM, Esposito G, et al. Placental morphology, apoptosis, angiogenesis and epithelial mechanisms in early-onset preeclampsia. Eur J Obstet Gynecol Reprod Biol. 2019;234:200-6.

70. Chen J, Yue C, Xu J, Zhan Y, Zhao H, Li Y, et al. Downregulation of receptor tyrosine kinase-like orphan receptor 1 in preeclampsia placenta inhibits human trophoblast cell proliferation, migration, and invasion by $\mathrm{PI} 3 \mathrm{~K} / \mathrm{AKT} / \mathrm{mTOR}$ pathway accommodation. Placenta. 2019;82:17-24.

71. Torry DS, Wang HS, Wang TH, Caudle MR, Torry RJ. Preeclampsia is associated with reduced serum levels of placenta growth factor. Am J Obstet Gynecol. 1998;179:1539-44.

72. Taylor RN, Grimwood J, Taylor RS, McMaster MT, Fisher SJ, North RA. Longitudinal serum concentrations of placental growth factor: evidence for abnormal placental angiogenesis in pathologic pregnancies. Am J Obstet Gynecol. 2003;188:177-82.

73. Tsatsaris V, Goffin F, Munaut C, Brichant JF, Pignon MR, Noel A, et al. Overexpression of the soluble vascular endothelial growth factor receptor in preeclamptic patients: pathophysiological consequences. J Clin Endocrinol Metab. 2003;88:5555-63.

74. Maynard SE, Min JY, Merchan J, Lim KH, Li J, Mondal S, et al. Excess placental soluble fms-like tyrosine kinase 1 (sFlt1) may contribute to endothelial dysfunction, hypertension, and proteinuria in preeclampsia. J Clin Invest. 2003;111:649-58.

75. Levine RJ, Maynard SE, Qian C, Lim KH, England LJ, Yu KF, et al. Circulating angiogenic factors and the risk of preeclampsia. N Engl J Med. 2004;350:672-83.

76. Chaiworapongsa T, Romero R, Kim YM, Kim GJ, Kim MR, Espinoza J, et al. Plasma soluble vascular endothelial growth factor receptor-1 concentration is elevated prior to the clinical diagnosis of pre-eclampsia. J Matern Fetal Neonatal Med. 2005;17:318.

77. Wathén KA, Tuutti E, Stenman UH, Alfthan H, Halmesmäki E, Finne $\mathrm{P}$, et al. Maternal serum-soluble vascular endothelial growth factor receptor-1 in early pregnancy ending in preeclampsia or intrauterine growth retardation. J Clin Endocrinol Metab. 2006;91:180-4.

78. Levine RJ, Lam C, Qian C, Yu KF, Maynard SE, Sachs BP, et al. Soluble endoglin and other circulating antiangiogenic factors in preeclampsia. N Engl J Med. 2006;355:992-1005.

79. Myatt L, Clifton RG, Roberts JM, Spong CY, Hauth JC, Varner MW, et al. First-trimester prediction of preeclampsia in nulliparous women at low risk. Obstet Gynecol. 2012;119:1234-42.

80. Kenny LC, Black MA, Poston L, Taylor R, Myers JE, Baker PN, et al. Early pregnancy prediction of preeclampsia in nulliparous women, combining clinical risk and biomarkers: the screening for pregnancy endpoints (SCOPE) international cohort study. Hypertension. 2014;64:644-52.

81. Serin IS, Kula M, Başbuğ M, Unlühizarci K, Güçer S, Tayyar M. Androgen levels of preeclamptic patients in the third trimester of pregnancy and six weeks after delivery. Acta Obstet Gynecol Scand. 2001;80:1009-13.

82. Zeisler H, Jirecek S, Hohlagschwandtner M, Knöfler M, Tempfer $\mathrm{C}$, Livingston JC. Concentrations of estrogens in patients with preeclampsia. Wien Klin Wochenschr. 2002;114:458-61.

83. Miller NR, Garry D, Cohen HW, Figueroa R. Serum androgen markers in preeclampsia. J Reprod Med. 2003;48:225-9.

84. Salas SP, Marshall G, Gutiérrez BL, Rosso P. Time course of maternal plasma volume and hormonal changes in women with preeclampsia or fetal growth restriction. Hypertension. 2006;47: 203-8.

85. Hertig A, Liere P, Chabbert-Buffet N, Fort J, Pianos A, Eychenne $\mathrm{B}$, et al. Steroid profiling in preeclamptic women: evidence for aromatase deficiency. Am J Obstet Gynecol. 2010;203:477.e1-9. 
86. Berkane N, Liere P, Oudinet JP, Hertig A, Lefèvre G, Pluchino N, et al. From pregnancy to preeclampsia: a key role for estrogens. Endocr Rev. 2017;38:123-44.

87. Jobe SO, Tyler CT, Magness RR. Aberrant synthesis, metabolism, and plasma accumulation of circulating estrogens and estrogen metabolites in preeclampsia implications for vascular dysfunction. Hypertension. 2013;61:480-7.

88. Faas MM, De Vos P. Innate immune cells in the placental bed in healthy pregnancy and preeclampsia. Placenta. 2018;29:125-33.

89. Stallmach T, Hebisch G, Orban P, Lu X. Aberrant positioning of trophoblast and lymphocytes in the feto-maternal interface with pre-eclampsia. Virchows Arch. 1999;434(3):07-211.

90. Bachmayer N, Rafik Hamad R, Liszka L, Bremme K, Sverremark-Ekstrom E. Aberrant uterine natural killer (NK)-cell expression and altered placental and serum levels of the NK-cell promoting cytokine interleukin-12 in pre-eclampsia. Am J Reprod Immunol. 2006;56(5-6):292-301.

91. Wilczyński JR, Tchórzewski H, Banasik M, Głowacka E, Wieczorek A, Lewkowicz P, et al. Lymphocyte subset distribution and cytokine secretion in third trimester decidua in normal pregnancy and preeclampsia. Eur J Obstet Gynecol Reprod Biol. 2003;109(1):8-15.

92. Schonkeren D, van der Hoorn ML, Khedoe P, Swings G, van Beelen E, Claas F, et al. Differential distribution and phenotype of decidual macrophages in preeclamptic versus control pregnancies. Am J Pathol. 2011;178(2):709-17.

93. Reister F, Frank HG, Kingdom JC, Heyl W, Kaufmann P, Rath W, et al. Macrophage-induced apoptosis limits endovascular trophoblast invasion in the uterine wall of preeclamptic women. Lab Investig. 2001;81(8):1143-52.

94. Kim JS, Romero R, Cushenberry E, Kim YM, Erez O, Nien JK, et al. Distribution of CD14+ and CD68+ macrophages in the placental bed and basal plate of women with preeclampsia and preterm labor. Placenta. 2007;28(5-6):571-6.

95. Williams PJ, Bulmer JN, Searle RF, Innes BA, Robson SC. Altered decidual leucocyte populations in the placental bed in pre-eclampsia and foetal growth restriction: a comparison with late normal pregnancy. Reproduction. 2009;138(1):177-84.

96. Eide IP, Rolfseng T, Isaksen CV, Mecsei R, Roald B, Lydersen S, et al. Serious foetal growth restriction is associated with reduced proportions of natural killer cells in decidua basalis. Virchows Arch. 2006;448(3):269-76.

97. Bürk MR, Troeger C, Brinkhaus R, Holzgreve W, Hahn S. Severely reduced presence of tissue macrophages in the basal plate of pre-eclamptic placentae. Placenta. 2001;22(4):309-16.

98. Rieger L, Segerer S, Bernar T, Kapp M, Majic M, Morr AK, et al. Specific subsets of immune cells in human decidua differ between normal pregnancy and preeclampsia-a prospective observational study. Reprod Bio Endocrino: RBE (Rev Bras Entomol). 2009;7: 132.

99. Hsu P, Santner-Nanan B, Dahlstrom JE, Fadia M, Chandra A, Peek M, et al. Altered decidual DC-SIGN+ antigen-presenting cells and impaired regulatory $\mathrm{T}$-cell induction in preeclampsia. Am J Pathol. 2012;181(6):2149-60.

100. Huang SJ, Chen CP, Schatz F, Rahman M, Abrahams VM, Lockwood CJ. Pre-eclampsia is associated with dendritic cell recruitment into the uterine decidua. J Pathol. 2008;214(3):328-36.

101. Hiby SE, Walker JJ, O'Shaughnessy KM, Redman CW, Carrington M, Trowsdale J, et al. Combinations of maternal KIR and fetal HLA-C genes influence the risk of preeclampsia and reproductive success. J Exp Med. 2004;200(8):957-65.

102. Reister F, Frank HG, Heyl W, Kosanke G, Huppertz B, Schröder $\mathrm{W}$, et al. The distribution of macrophages in spiral arteries of the placental bed in pre-clampsia differs from that in healthy patients. Placenta. 1999;20((2-3)):229-33
103. Katabuchi H, Yih S, Ohba T, Matsui K, Takahashi K, Takeya M, et al. Characterization of macrophages in the decidual atherotic spiral artery with special reference to the cytology of foam cells. Med Electron Microsc. 2003;36(4):253-62.

104. Haeger M, Unander M, Norder-Hansson B, Tylman M, Bengtsson A. Complement, neutrophil, and macrophage activation in women with severe preeclampsia and the syndrome of hemolysis, elevated liver enzymes, and low platelet count. Obstet Gynecol. 1992;79(1):19-26.

105. Benyo DF, Smarason A, Redman CW, Sims C, Conrad KP. Expression of inflammatory cytokines in placentas from women with preeclampsia. J Clin Endocrinol Metab. 2001;86(6):250512.

106. Wang Y, Walsh SW. TNF alpha concentrations and mRNA expression are increased in preeclamptic placentas. J Reprod Immunol. 1996;32(2):157-69.

107. Pang ZJ, Xing FQ. Comparative study on the expression of cytokine-receptor genes in normal and preeclamptic human placentas using DNA microarrays. J Perinat Med. 2003;31(2):15362.

108. Hennessy A, Pilmore HL, Simmons LA, Painter DM. A deficiency of placental IL-10 in preeclampsia. J Immunol. 1999;163(6): 3491-5.

109. Rein DT, Breidenbach M, Hönscheid B, Friebe-Hoffmann U, Engel H, Göhring UJ, et al. Preeclamptic women are deficient of interleukin-10 as assessed by cytokine release of trophoblast cells in vitro. Cytokine. 2003;23(4-5):119-25.

110. Prins JR, Faas MM, Melgert BN, Huitema S, Timmer A, Hylkema $\mathrm{MN}$, et al. Altered expression of immune-associated genes in firsttrimester human decidua of pregnancies later complicated with hypertension or foetal growth restriction. Placenta. 2012;33(5): 453-5.

111. Redman CW, Sargent IL, Staff AC. IFPA Senior Award Lecture: making sense of preeclampsia-two placental causes of preeclampsia? Placenta. 2014;35(Suppl):S20-5.

112. Roberts JM, Taylor RN, Musci TJ, Rodgers GM, Hubel CA, Mclaughlin MK. Preeclampsia: an endothelial cell disorder. Am J Obstet Gynecol. 1989;161:1200-4.

113. Barden A, Beilin LJ, Ritchie J, Walters BN, Michael CA. Plasma and urinary endothelin 1 , prostacyclin metabolites and platelet consumption in pre-eclampsia and essential hypertensive pregnancy. Blood Press. 1994;3:38-46.

114. Walsh SW. Maternal-placental interactions of oxidative stress and antioxidants in preeclampsia. Semin Reprod Endocrinol. 1998;16: 93-104.

115. Myatt L, Webster RP. Vascular biology of preeclampsia. J Thromb Haemost. 2009;7:375-84.

116. Cunningham FG, Roberts JM, Lindheimer MD. The clinical spectrum of preeclampsia. In: Lindheimer MD, Roberts JM, Cunningham FG, editors. Chesley's hypertensive disorders in pregnancy. San Diego: Academic; 2009. p. 25-36.

117. Redman CW, Sargent IL. Placental stress and pre-eclampsia: a revised view. Placenta. 2009;30(Suppl A):S38-42.

118. Brennan LJ, Morton JS, Davidge ST. Vascular dysfunction in preeclampsia. Microcirculation. 2014;21:4-14.

119. Goulopoulou S, Davidge ST. Molecular mechanisms of maternal vascular dysfunction in preeclampsia. Trends Mol Med. 2015;21: 88-97.

120. Khalil RA, Granger JP. Vascular mechanisms of increased arterial pressure in preeclampsia: lessons from animal models. Am J Physiol Regul Integr Comp Physiol. 2002;283:R29-45.

121. Ilekis JV, Tsilou E, Fisher S, Abrahams VM, Soares MJ, Cross JC, et al. Placental origins of adverse pregnancy outcomes: potential molecular targets: an Executive Workshop Summary of the Eunice Kennedy Shriver National Institute of Child Health and Human Development. Am J Obstet Gynecol. 2016;215:S1-S46. 
122. Sladek SM, Magness RR, Conrad KP. Nitric oxide and pregnancy. Am J Phys. 1997;272:R441-63.

123. Hood JD, Meininger CJ, Ziche M, Granger HJ. VEGF upregulates ecNOS message, protein, and NO production in human endothelial cells. Am J Phys. 1998;274:H1054-8.

124. Ferrara N, Gerber HP, LeCouter J. The biology of VEGF and its receptors. Nat Med. 2003;9:669-76.

125. Venkatesha S, Toporsian M, Lam C, Hanai J, Mammoto T, Kim $\mathrm{YM}$, et al. Soluble endoglin contributes to the pathogenesis of preeclampsia. Nat Med. 2006;12(6):642-9 Epub 2006 Jun 4.

126. Lu F, Longo M, Tamayo E, Maner W, Al-Hendy A, Anderson GD, et al. The effect of over-expression of sFlt-1 on blood pressure and the occurrence of other manifestations of preeclampsia in unrestrained conscious pregnant mice. Am J Obstet Gynecol. 2007;196:396.e1-7.

127. Tang JR, Karumanchi SA, Seedorf G, Markham N, Abman SH. Excess soluble vascular endothelial growth factor receptor-1 in amniotic fluid impairs lung growth in rats: linking preeclampsia with bronchopulmonary dysplasia. Am J Physiol Lung Cell Mol Physiol. 2012;302:L36-46.

128. LaMarca BD, Gilbert JS, Granger JP. Recent progress toward the understanding of the pathophysiology of hypertension during preeclampsia. Hypertension. 2008;51:982-8.

129. Suzuki H, Ohkuchi A, Matsubara S, Takei Y, Murakami M, Shibuyua M, et al. Effect of recombinant placental growth factor 2 on hypertension induced by full-length mouse soluble fms-like tyrosine kinase 1 adenoviral vector in pregnant mice. Hypertension. 2009;54:11291135.

130. Bridges JP, Gilbert JS, Colson D, Gilbert SA, Dukes MP, Ryan MJ, et al. Oxidative stress contributes to soluble fms-like tyrosine kinase-1 induced vascular dysfunction in pregnant rats. Am J Hypertens. 2009;22:564-8 Epub 2009 Mar 5.

131. Szalai G, Romero R, Chaiworapongsa T, Xu Y, Wang B, Ahn H, et al. Full-length human placental sFlt-1-e15a isoform induces distinct maternal phenotypes of preeclampsia in mice. PLoS One. 2015;10(4): 0119547.

132. Khankin EV, Mandala M, Colton I, Karumanchi SA, Osol G. Hemodynamic, vascular, and reproductive impact of FMS-like tyrosine kinase 1 (FLT1) blockade on the uteroplacental circulation during normal mouse pregnancy. Biol Reprod. 2012;86:57,18.

133. Li Z, Zhang Y, Ying Ma J, Kapoun AM, Shao Q, Kerr I, et al. Recombinant vascular endothelial growth factor 121 attenuates hypertension and improves kidney damage in a rat model of preeclampsia. Hypertension. 2007;50:686-92.

134. Bergmann A, Ahmad S, Cudmore M, Gruber AD, Wittschen P, Lindenmaier W, et al. Reduction of circulating soluble Flt-1 alleviates preeclampsia-like symptoms in a mouse model. J Cell Mol Med. 2010;14:1857-67.

135. Gilbert JS, Verzwyvelt J, Colson D, Arany M, Karumanchi SA, Granger JP. Recombinant vascular endothelial growth factor 121 infusion lowers blood pressure and improves renal function in rats with placental ischemia-induced hypertension. Hypertension. 2010;55:380-385.

136. Woods AK, Hoffmann DS, Weydert CJ, Butler SD, Zhou Y, Sharma RV, et al. Adenoviral delivery of VEGF121 early in pregnancy prevents spontaneous development of preeclampsia in BPH/5 mice. Hypertension. 2011;57:94-102.

137. Mateus J, Bytautiene E, Lu F, Tamayo EH, Betancourt A, Hankins GD, et al. Endothelial growth factor therapy improves preeclampsia-like manifestations in a murine model induced by overexpression of sVEGFR-1. Am J Physiol Heart Circ Physiol. 2011;301:H1781-7.

138. Carr DJ, Wallace JM, Aitken RP, Milne JS, Martin JF, Zachary IC, et al. Peri- and postnatal effects of prenatal adenoviral VEGF gene therapy in growth-restricted sheep. Biol Reprod. 2016;94: $142,1-12$.

139. Kumasawa K, Ikawa M, Kidoya H, Hasuwa H, Saito-Fujita T, Morioka Y, et al. Pravastatin induces placental growth factor (PGF) and ameliorates preeclampsia in a mouse model. Proc Natl Acad Sci U S A. 2011;108:1451-5.

140. Rejinders D, Liu CC, Xu X, Zhao AM, Olson KN, Butler SD, et al. Celecoxib restores angioogenic factor expression at the maternal-fetal interface in the $\mathrm{BPH} / 5$ mouse model of preeclampsia. Physiol Genomics. 2018;50(5):385-92.

141. Aasa KL, Zavan B, Luna RL, Wong PG, Ventura NM, Tse MY, et al. Placental growth factor influences maternal cardiovascular adaptation to pregnancy in mice. Biol Reprod. 2015;92:44.

142. Kay VR, Rätsep MT, Figueiró-Filho EA, Croy BA. Preeclampsia may influence offspring neuroanatomy and cognitive function: a role for placental growth factor. Biol Reprod. 2019;101:271-83.

143. LaMarca BB, Bennett WA, Alexander BT, Cockrell K, Granger JP. Hypertension produced by reductions in uterine perfusion in the pregnant rat: role of tumor necrosis factor $-\alpha$. Hypertension. 2005;46:1022-5.

144. Gilbert JS, Babcock SA, Granger JP. Hypertension produced by reduced uterine perfusion in pregnant rats is associated with increased soluble fms-like tyrosine kinase-1 expression. Hypertension. 2007;50:1142-7 Epub 2007 Oct 8.

145. Walsh SK, English FA, Johns EJ, Kenny LC. Plasma-mediated vascular dysfunction in the reduced uterine perfusion pressure model of preeclampsia: a microvascular characterization. Hypertension. 2008;54:345-51.

146. Lin, C, He H, Cui N, Ren Z, Zhu M, Khalil RA. Decreased uterine vascularization and uterine arterial expansive remodeling with reduced matrix metalloproteinase- 2 and -9 in hypertensive pregnancy. Am J Physiol Heart Circ Physiol. 2019;318(1):H165-H180.

147. Molnár M, Sütö T, Tóth T, Hertelendy F. Prolonged blockade of nitric oxide synthesis in gravid rats produces sustained hypertension, proteinuria, thrombocytopenia, and intrauterine growth retardation. Am J Obstet Gynecol. 1994;170:1458-66.

148. Winship AL, Koga K, Menkhorst E, Van Sinderen M, Rainczuk K, Nagai M, et al. Interleukin-11 alters placentation and causes preeclampsia features in mice. Proc Natl Acad Sci U S A. 2015; 112:15928-33.

149. Kulandavelu S, Whiteley KJ, Qu D, Mu J, Bainbridge SA, Adamson SL. Endothelial nitric oxide synthase deficiency reduces uterine blood flow, spiral artery elongation, and placental oxygenation in pregnant mice. Hypertension. 2012;60:231-8.

150. Cureton N, Kortokova I, Baker B, Greenwood S, Wareing M, Kotamraju VR, et al. Selective targeting of a novel vasodilator to the uterine vasculature to treat impaired uteroplacental perfusion in pregnancy. Theronastics. 2017;7(15):3715-31 eCollection 2017.

151. Hunkapillar NM, Gasperowicz M, Kapidzic M, Plaks V, Maltepe E, Kitajewski J, et al. A role for Notch signaling in trophoblast endovascular invasion and in the pathogenesis of pre-eclampsia. Development. 2011;138:2987-98.

152. Doridot L, Passet B, Méhats C, Rigourd V, Barbaux S, Ducat A, et al. Preeclampsia-like symptoms induced in mice by fetoplacental expression of STOX1 are reversed by aspirin treatment. Hypertension. 2013;61:662-8.

153. Greenwood JD, Minhas K, di Santo JP, Makita M, Kiso Y, Croy BA. Ultrastructural studies of implantation sites from mice deficient in uterine natural killer cells. Placenta. 2000;21:693-702.

154. Ashkar AA, Di Santo JP, Croy BA. Interferon gamma contributes to initiation of uterine vascular modification, decidual integrity, and uterine natural killer cell maturation during normal murine pregnancy. J Exp Med. 2000;192:259-70.

155. Croy BA, He H, Esadeg S, Wei Q, McCartney D, Zhang J, et al. Uterine natural killer cells: insights into their cellular and 
molecular biology from mouse modelling. Reproduction. 2003;126:149-60.

156. Monk JM, Leonard S, McBey BA, Croy BA. Induction of murine spiral artery modification by recombinant human interferon-gamma. Placenta. 2005;26:835-8.

157. Nadkarni S, Smith J, Sferruzzi-Perri AN, Ledwozyw A, Kishore M, Haas R, et al. Neutrophils induce proangiogenic T cells with a regulatory phenotype in pregnancy. Proc Natl Acad Sci U S A. 2016;113:E8415-24.

158. Care AS, Bourque SL, Morton JS, Hjartarson EP, Robertson SA, Davidge ST. Reduction in regulatory T cells in early pregnancy causes uterine dysfunction in mice. Hypertension. 2018;72:17787.

159. Robertson SA, Care AS, Moldenhauer LM. Regulatory T cells in embryo implantation and the immune response to pregnancy. J Clin Invest. 2018;128:4225-35.

160. Zhou CC, Zhang Y, Irani RA, Zhang H, Mi T, Popek EJ, et al. Angiotensin receptor agnostic autoantibodies induce preeclampsia in pregnant mice. Nat Med. 2008;14:855-62 Epub 2008 Jul 27.

161. Parrish MR, Murphy SP, Rutland S, Wallace K, Wenzel K, Wallukat $\mathrm{G}$, et al. The effect of immune factors, tumor necrosis factor-alpha, and agonistic autoantibodies to the angiotensin II type I receptor on soluble fms-like tyrosine-1 and soluble endoglin production in response to hypertension during pregnancy. Am J Hypertens. 2010;23:911-6 Epub 2010 Apr 29.

162. Walther T, Jank A, Heringer-Walther S, Horn LC, Stepan H. Angiotensin II type 1 receptor has impact on murine placentation. Placenta. 2008;29:905-9.

163. Geusens N, Hering L, Verlohren S, Luyten C, Drijkoningen K, Taube M, et al. Changes in endovascular trophoblast invasion and spiral artery remodelling at term in a transgenic preeclamptic rat model. Placenta. 2010;31:320-6.

164. Quitterer U, Fu X, Pohl A, Bayoumy KM, Langer A, Abdalla S. Beta-arrestin 1 prevents preeclampsia by downregulation of mechanosensitive AT1-B2 receptor heteromers. Cell. 2019;176: 318-333.e19.

165. Albrecht ED, Pepe GJ. Endocrinology of pregnancy. In: Brans YW, Kuehl TJ, editors. Non-human primates in perinatal research. New York: John Wiley and Sons; 1988. p. 13-78.

166. Malassine A, Frendo JL, Evain-Brion D. A comparison of placental development and endocrine functions between the human and mouse model. Hum Reprod Update. 2003;9:531-9.

167. Osol G, Mandala M. Maternal uterine vascular remodeling during pregnancy. Physiology (Bethesda). 2009;24:58-71.

168. McCarthy FP, Kingdom JC, Kenny LC, Walsh SK. Animal models of preeclampsia; uses and limitations. Placenta. 2011;32: 413-9.

169. Georgiades P, Ferguson-Smith AC, Burton GJ. Comparative developmental anatomy of the murine and human definitive placentae. Placenta. 2002;23:3-19.

170. Silva JF, Serakides R. Intrauterine trophoblast migration: a comparative view of humans and rodents. Cell Adhes Migr. 2016;10: $88-110$.

171. Marshall SA, Hannan NJ, Jelinic M, Nguyen TPH, Girling JE, Parry LJ. Animal models of preeclampsia: translational failings and why. Am J Physiol Regul Integr Comp Physiol. 2018;314: R499-508.

172. Adamson SL, Lu Y, Whiteley KJ, Homyard D, Hemberger M, Pfarrer C, et al. Interactions between trophoblast cells and the maternal and fetal circulation in the mouse placenta. Dev Biol. 2002;250(2):358-73
173. Schlabritz-Loutsevitch NE, Hubbard GB, Jenkins SL, Martin HC, Snider CS, Frost PA, et al. Ontogeny of hematological cell and biochemical profiles in maternal and fetal baboons (Papio species). J Med Primatol. 2005;34:193-200.

174. Enders AC, Blankenship TN, Fazleabas AT, Jones CJ. Structure of anchoring villi and the trophoblastic shell in the human, baboon and macaque placenta. Placenta. 2001;22:284-303.

175. VandeBerg JL, Williams-Blangero S. Advantages and limitations of nonhuman primates as animal models in genetic research on complex diseases. J Med Primatol. 1997;26:113-9.

176. Cox LA, Mahaney MC, Vandeberg JL, Rogers J. A secondgeneration genetic linkage map of the baboon (Papio hamadryas) genome. Genomics. 2006;88:274-81.

177. Cavanagh D, Rao PS, Tsai CC, O'Connor TC. Experimental toxemia in the pregnant primate. Am J Obstet Gynecol. 1977;128:7585.

178. Makris A, Thornton C, Thompson J, Thomson S, Martin R, Ogle $\mathrm{R}$, et al. Uteroplacental ischemia results in proteinuric hypertension and elevated sFLT-1. Kidney Int. 2007;71:977-84.

179. Makris A, Yeung KR, Lim SM, Sunderland N, Heffernan S, Thompson JF, et al. Placental growth factor reduces blood pressure in a uteroplacental ischemia model of preeclampsia in nonhuman primates. Hypertension. 2016;67:1263-72.

180. Turanov AA, Lo A, Hassler MR, Makris A, Ashar-Patel A, Alterman JF, et al. RNAi modulation of placental sFLT1 for the treatment of preeclampsia. Nat Biotechnol. 2018;36:1164-1173.

181. Bonagura TW, Pepe GJ, Enders AC, Albrecht ED. Suppression of extravillous trophoblast vascular endothelial growth factor expression and uterine spiral artery invasion by estrogen during early baboon pregnancy. Endocrinology. 2008;149:5078-87.

182. Bonagura TW, Babischkin JS, Aberdeen GW, Pepe GJ, Albrecht ED. Prematurely elevating estradiol in early baboon pregnancy suppresses uterine artery remodeling and expression of extravillous placental vascular endothelial growth factor and $\alpha 1 \beta 1$ and $\alpha 5 \beta 1$ integrins. Endocrinology. 2012;153:2897-906.

183. Aberdeen GW, Bonagura TW, Harman CR, Pepe GJ, Albrecht ED. Suppression of trophoblast uterine spiral artery remodeling by estrogen during baboon pregnancy: impact on uterine and fetal blood flow dynamics. Am J Physiol Heart Circ Physiol. 2012;302: H1936-44.

184. Babischkin JS, Aberdeen GW, Lindner JR, Bonagura TW, Pepe GJ, Albrecht ED. Vascular endothelial growth factor delivery to placental basal plate promotes uterine artery remodeling in the primate. Endocrinology. 2019;160:1492-505.

185. Aplin JD, Haigh T, Jones CJ, Church HJ, Viovac L. Development of cytrophoblast columns from explanted first trimester human placental villi: role of fibronectin and integrin $\alpha 5 \beta 1$. Biol Reprod. 1999;60:828838.

186. Irving JA, Lala PK. Functional role of cell surface integrins on human trophoblast cell migration: regulation by TGF $\beta$, IGF-II, and IGFBP-1. Exp Cell Res. 1995;217:419427.

187. Fukushima K, Miyamoto S, Tsukimori K, Kobayashi H, Seki H, Takeda S, et al. Tumor necrosis factor and vascular endothelial growth factor induce endothelial integrin repertories, regulating endovascular differentiation and apoptosis in a human extravillous trophoblast cell line. Biol Reprod. 2005;73:172-9.

Publisher's Note Springer Nature remains neutral with regard to jurisdictional claims in published maps and institutional affiliations. 